\title{
Selection, Procurement, and Description of Salem Limestone Samples Used to Study Effects of Acid Rain
}

U.S. Geological Survey

Reston, Virginia 22092

and

U.S. DEPARTMENT OF COMMERCE

National Bureau of Standards

National Engineering Laboratory

Center for Building Technology

Gaithersburg, MD 20899

July 1984

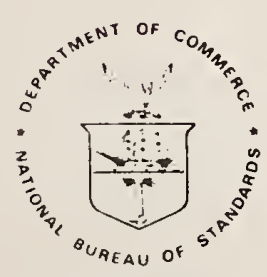

U.S. DEPARTMENT OF COMMERCE NATIONAL BUREAU OF STANDARDS 

NBSIR 84-2905

\section{SELECTION, PROCUREMENT, AND}

DESCRIPTION OF SALEM LIMESTONE

SAMPLES USED TO STUDY EFFECTS OF

ACID RAIN

Malcolm .Ross

U.S. Geological Survey

Reston, Virginia 22092

and

Larry Knab

U.S. DEPARTMENT OF COMMERCE

National Bureau of Standards

National Engineering Laboratory

Center for Building Technology

Gaithersburg, MD 20899

July 1984

U.S. DEPARTMENT OF COMMERCE, Malcolm Baldrige, Secretary NATIONAL BUREAU OF STANDARDS. Emeat Ambler, Diroctor 



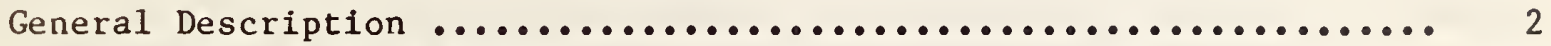

Procurement of study Block ............................. 4

Cutting, Planing, and Labeling of Study Block ................ 4

ACKNOWLEDGEMENT $\ldots \ldots \ldots \ldots \ldots \ldots \ldots \ldots \ldots \ldots \ldots \ldots \ldots \ldots \ldots \ldots \ldots \ldots \ldots \ldots \ldots \ldots \ldots \ldots \ldots$

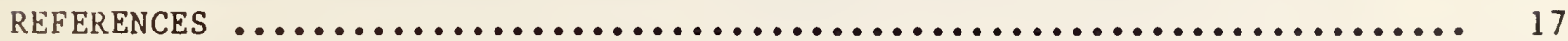


Figure 1. Map of Lawrence and Monroe Counties showing area of outcrop of Salem Limestone and also locations of quarries active in September, 1981 (after Patton, 1982). The location of

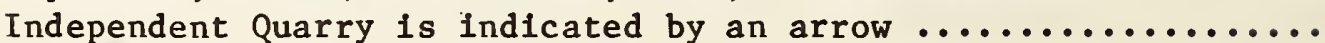

Figure 2. Ledge No. 2 (foreground), Independent Quarry, Bloomington, Indiana, from which the study block of limestone was quarried. The approximate former location of the block is shown by the black arrow (lower part of the face of Ledge No. 2). The tip of the white arrow points to the top of the Salem Limestone formation. Above the Salem Limestone (top of photograph) lies the St. Louis Limestone formation .......................

Figure 3. Salem Limestone study block removed from Ledge No. 2, Independent Quarry, Bloomington, Indiana (figure 2). This block of approximate dimensions $3.5 \times 4 \times 9$ feet was cut into thirteen $2 \times 48 \times$ 108 inch slices and one $4 \times 48 \times 108$ inch slice ............

Figure 4a. Study block in saw (right side, arrow) being gang sawn into thirteen 2 inch and one 4 inch thick slices.

4b. Close-up of study block after gang sawing ................

Figure 5. Three $2 \times 48 \times 108$ inch slices being sawn in half $\ldots \ldots \ldots \ldots \ldots$

Figure 6. One $24 \times 108$ inch surface being planed to a "smooth planar

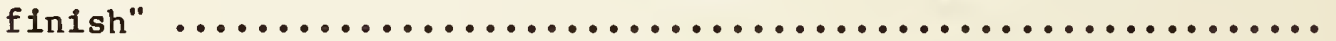

Figure 7. Six $2 \times 24 \times 108$ inch half-slices that were sawn into forty-

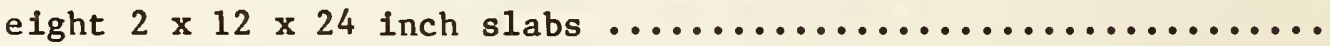

Figure 8. Labeling scheme used to indicate relative location and orientation of the two-hundred-and-twenty-four $12 \times 24$ inch slabs within the original Salem Limestone study block. The top slice of the block is on the top of the figure and includes slabs AU1 to AU8 and AL1 to AL8. The bottom slice of the block, at the bottom of the figure, includes slabs NU1 to NU8 and NL1 to NL8. Slabs A through $M$ are all 2 inches thick; the $N$ slabs are 4 inches thick. All slabs are: (1) labeled with a two-letter, one-number designation (e.g., $A U 3)$, and (2) marked with an arrow pointing to the upper $12 \times 24$ inch surface, the surface lying closest to the top of the original quarried block and having the "smooth planar finish" .......................................

Figure 9. Numbering scheme used to determine location and orientation of twenty-four $2 \times 2-15 / 16 \times 3-1 / 4$ to $3-1 / 2$ inch briquettes cut from "L" slabs (AL1, AL2, ..., ML8) or "U" slabs(AU1, AU2, ..., MU8)-see figure 8. Each briquette has the slab designation (either " $\mathrm{L}$ " or "U") and a briquette number (01 to 24$)$ on it .............. 14 


\section{INTRODUCTION}

As part of the National Acid Precipitation Assessment Program (NAPAP), the research goal of the Materials Effects Task Group is to assess the damage caused by acid deposition on selected building materials, including dimension* stone. One of the ways this damage is being assessed is by exposing dimension stone at various outdoor sites where acid deposition and other environmental parameters are being measured continuously. The change in properties of the exposed stone as compared to the unexposed stone will be measured and analyzed.

This report provides the rationale for choosing Salem Limestone to be one of several stone types to be exposed at the various sites. A geologic description is provided and information on sample preparation, including cutting, surface finishing, and labeling, is given.

* Dimension stone refers to stone precut and shaped to specified sizes (Handbook, Indiana Limestone Institute of America, Inc., 1982-83) 
Salem Limestone was selected for the following reasons: (1) its widespread use as a dimension stone in the central, eastern, and northeastern regions of the United States, (2) its susceptibility to dissolution and deterioration in acidic environments, (3) its uniform texture and composition within a single quarry and among quarries, and (4) its ready availability from a quarry that has furnished stone for major U.S. building projects for over 50 years.

General Description

One of the most widely used building stones utilized in the United States is quarried in the Bloomington-Bedford area of south-central Indiana. Indiana dimension limestones are mostly quarried within the Salem Limestone sedimentary sequence, a stratigraphic unit 40 to 100 feet* thick which is Mississippian in age (approximately 350 million years). The Salem Limestone is overlain by the St. Louis Limestone and is underlain by the Harrodsburg Limestone. These latter two limestone units are not suitable for use as dimension stone. The active Salem Limestone quarries are for the most part restricted to Monroe and Lawrence counties (figure 1).

Salem Limestone is particularly useful both as a building stone and for statuary because it has no tendency to split in any preferential direction and is thus eminently suited for carving and complex milling; in the trade it is known as a "freestone" because of this property (Patton, 1974).

Salem Limestone was first quarried in 1827, and by 1968 approximately 55 million tons had been produced (Rooney, 1970, p. 25, figure 21). The stone is used in building construction in major mid-west and east coast cities and particularly in New York City and Washington, D.C. Notable buildings in which Salem Limestone was used in construction are: in New York City, the Empire State Building, the Rockefeller Center, and the Waldorf Astoria Hotel; and in Washington, D.C., the Washington National Cathedral, the National Archives, the Pentagon, and the Department of Interior Building. Information about the geology, quarrying, and use of Salem Limestone are given by McGregor (1963), Rooney (1970), and Patton (1982).

Salem Limestone is reported (McGregor, 1963) to be composed of approximately 98 percent $\mathrm{CaCO}_{3}, 1$ percent $\mathrm{MgCO}_{3}$, and 2 percent $\mathrm{SiO}_{2}$ in the form of quartz. Minor amounts of $\mathrm{Al}_{2} \mathrm{O}_{3}, \mathrm{Fe}_{2} \mathrm{O}_{3}, \mathrm{TiO}_{2}, \mathrm{~S}, \mathrm{P}_{2} \mathrm{O}_{5}$, and $\mathrm{MnO}$ have also been reported (McGregor, 1963).

* The stone industry uses the U.S. units of measurement and therefore these units are used in this report. SI length conversion factors are: 1 inch $=0.0254$ meter $(\mathrm{m})$ and 1 foot $=0.3048$ meter $(\mathrm{m})$. 


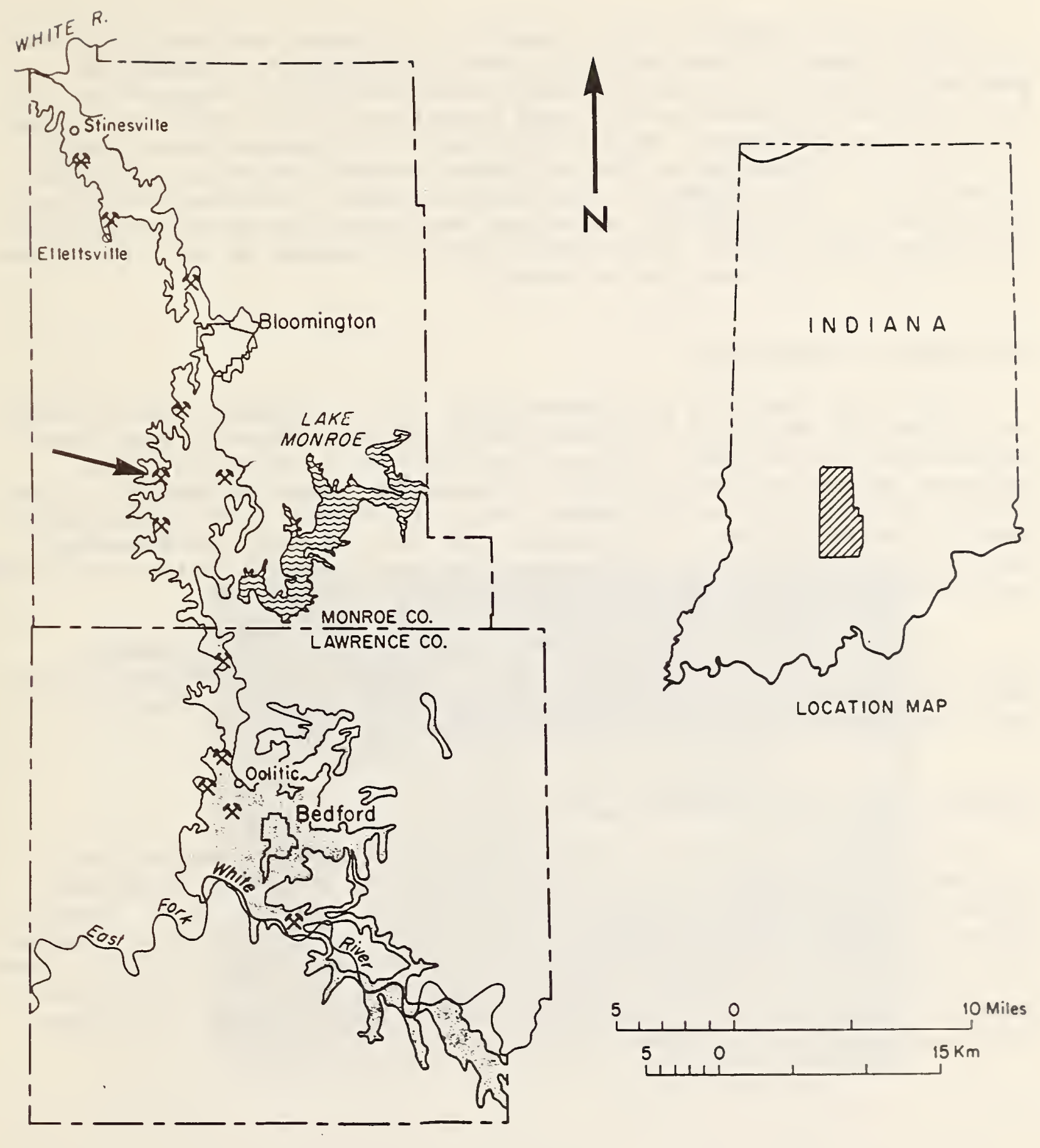

Figure 1. Map of Lawrence and Monroe Counties showing area of outcrop of Salem Limestone and also locations of quarries active in September, 1981 (after Patton, 1982). The location of Independent Quarry is Indicated by an arrow. 
Most of the limestone rock is composed of a diverse assortment of fossils and fossil fragments, some as much as several centimeters* in length but generally about $0.7 \mathrm{~mm}$ in average diameter (Patton, 1953). Fragments of lacy fenestrate bryozoans are the chief constituents of the rock; they average 0.2 to $1.0 \mathrm{~mm}$ in diameter. Next in abundance are echinoderm plates, chiefly from crinoids and blastoids. The third most abundant fossils are specimens of Endothyra. Small amounts of miscellaneous fossils are present sporadically, such as ostracods, gastropods, pelecypods, brachipods, sponge spicules, algae, and fishes (Smith, 1966). Interstitial calcite is present as late precipitated vein fillings; quartz may also be present.

\section{Procurement of Study Block}

Field trips were made by personnel from the U.S. Geological Survey (USGS), and the National Bureau of Standards (NBS) to the Bloomington, Indiana area in May and again in June 1983. The quarry selected to be the source of the limestone was the Independent Quarry** (Independent Limestone Company). This quarry, formerly known as the Shawnee Quarry, is located at 6001 South Rockport Road, 6.3 miles southwest of Bloomington, and has been producing dimension stone for over fifty years. It is noted that the Independent Quarry has furnished stone for the Washington National Cathedral since 1946.

A limestone block was selected for cutting into slabs for research study and was quarried in June 1983. The top of this study block was 19 feet below the top of the Salem Limestone formation. The location, Ledge No. 2, from which the study block was removed is shown in figure 2.

Cutting, Planing and Labeling of Study Block

The dimensions of the study block of limestone removed from the quarry ledge were approximately $3.5 \times 4 \times 9$ feet (figure 3 ). The study block was transported by railroad to the Bybee Cutting Mill** (Bybee Stone Co., Wilbur C. Bybee, President) at Ellettsville, Indiana, some 7 miles northwest of Bloomington. Here the study block was sawn into 208 slabs, measuring $2 \times 12 \times 24$ inches in size and 16 slabs measuring $4 \times 12 \times 24$ inches in size. The $12 \times 24$ inch faces of all slabs were orlented parallel to the bedding planes of the Salem Limestone formation (approximately horizontal).

* Fossil dimensions are given in metric units because metric units were used in the references.

** The quarry and cutting mill are identified for informational purposes only. This does not imply a recommendation or endorsement by the National Bureau of Standards or the U.S. Geological Survey. 


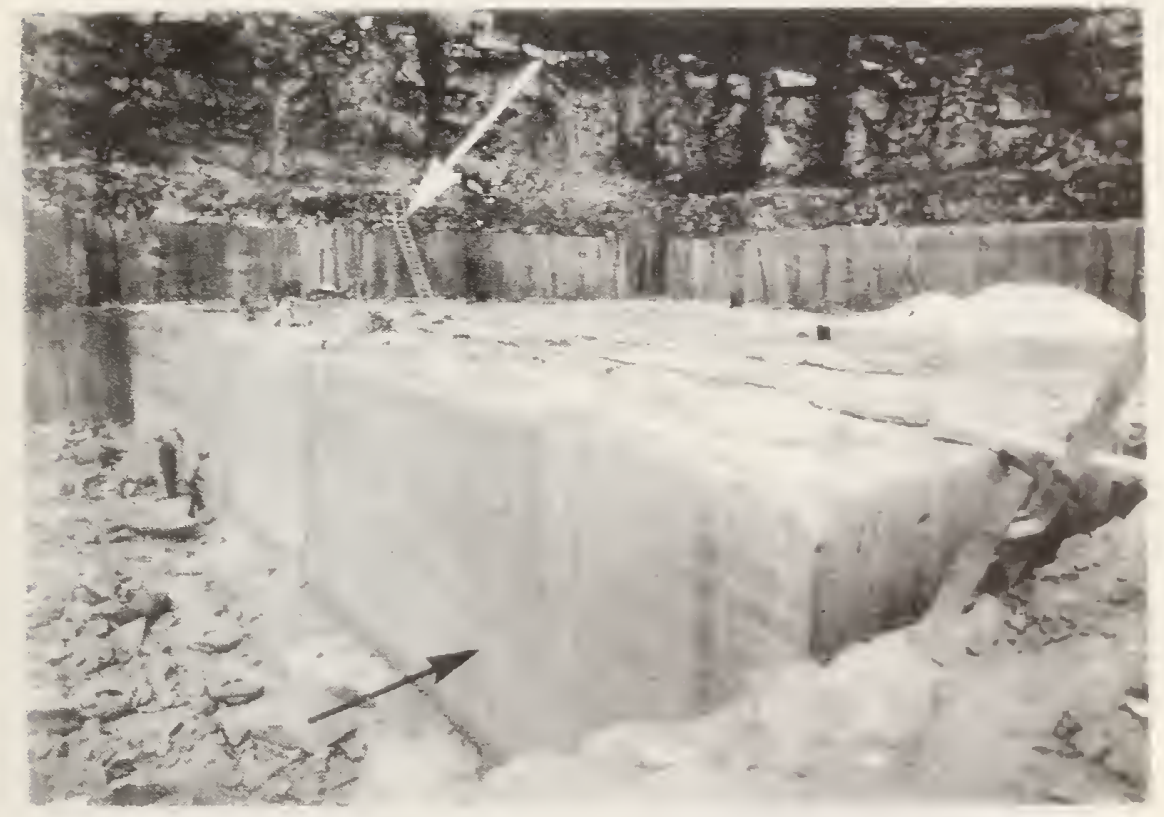

Figure 2. Ledge No. 2 (foreground), Independent Quarry, Bloomington, Indiana, from which the study block of limestone was quarried. The approx1mate former location of the block is shown by the black arrow (lower part of the face of Ledge No. 2). The tip of the white arrow points to the top of the Salem Limestone formation. Above the Salem Limestone (top of photograph) lies the St. Louls Limestone formation. 


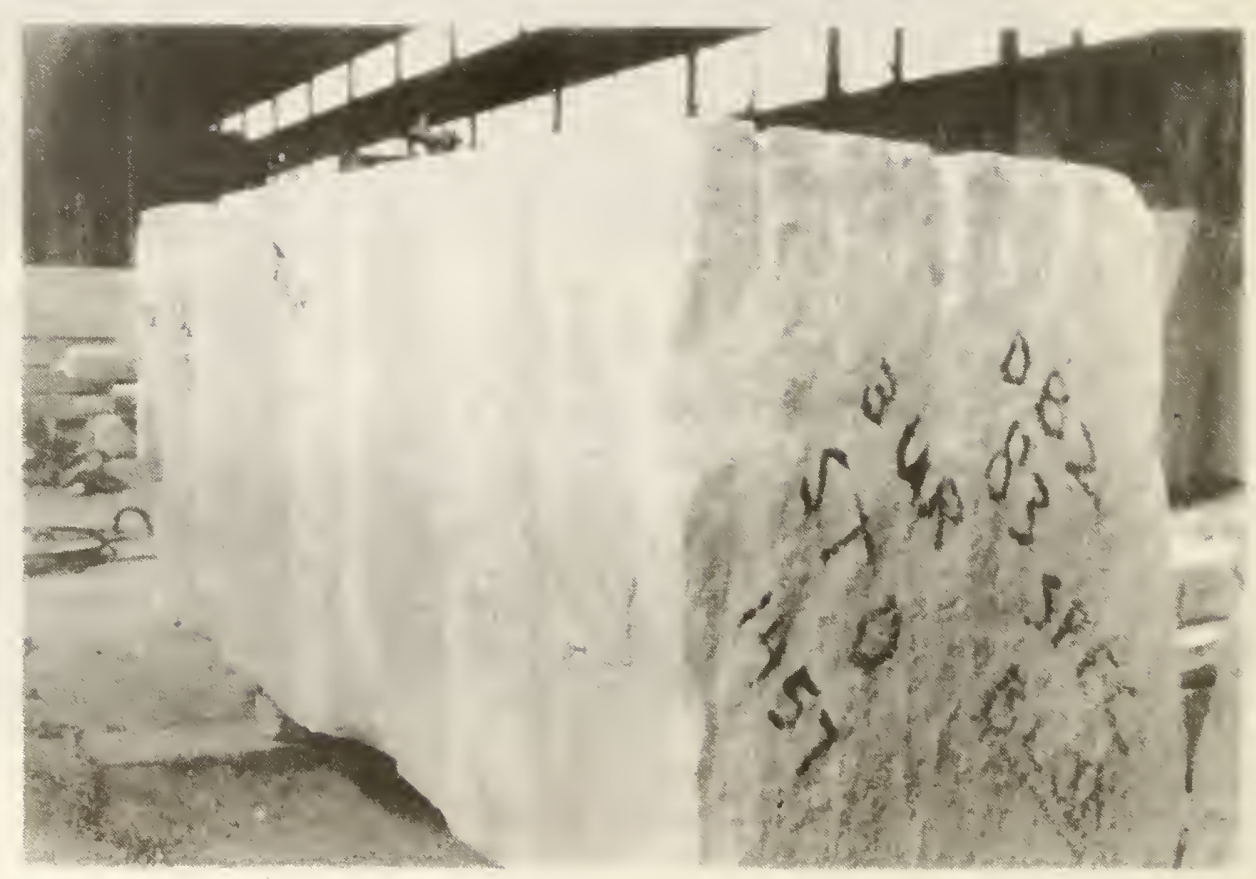

Figure 3. Salem Limestone study block removed from Ledge No. 2, Independent Quarry, Bloomington, Indiana (figure 2). This block of approximate dimensions $3.5 \times 4 \times 9$ feet was cut into thirteen $2 \times 48 \times$ 108 inch slices and one $4 \times 48 \times 108$ inch slice. 
The cutting of the slabs involved three steps. The study block was first gang sawn into 13 slices, each measuring approximately $2 \times 48 \times 108$ inches and 1 slice measuring approximately $4 \times 48 \times 108$ inches (figures $4 \mathrm{a}$ and $4 \mathrm{~b}$ ). The 2 inch thickness was chosen to minimize breakage. After further sawing into half-slices measuring 2 (or 4*) $\times 24 \times 108$ inches (figure 5), one $24 \times 108$ inch face of each half-slice was planed to a "smooth planar finish" (figure 6) which is a typical finish for Salem Limestone used in buildings. The half-slices were then sawn to the final $2 \times 12 \times 24$ inch (or $4 \times 12 \times 24$ inch) slabs (figure 7). Water from a nearby stream was used to cool and lubricate the saws. Surfaces planed to a "smooth planar finish" were protected by spacers during sawing, stacking, and shipping. Every slab was labeled on one of its 2 $\times 12$ or 4 x 12 inch ends during fabrication to indicate its relative location and orientation in the original study block (figure 8).

Twenty (table 1) of the two-hundred-and-eight $2 \times 12 \times 24$ inch slabs were discarded due to obvious defects which occurred during quarrying and fabrication. Twenty-four (table 1) of the $12 \times 24$ inch slabs (ten slabs 2 inches in thickness and fourteen slabs 4 inches in thickness) were provided to the Indiana Geological Survey to perform selected physical and mechanical tests to characterize the stone and for future testing. The remaining 180 slabs were shipped by truck to NBS in Gaithersburg, Maryland, and stored indoors at or near room temperature. A plastic cover was used to protect the stone from dust during shipping and storage.

The "G", "H", and "I" slabs located midway between the top and bottom of the study block (figure 8) were chosen to be used in the initial field exposure studies. It is intended that as additional stone is needed in these studies, slabs from adjacent slices (e.g., "F" and "J") will be used.

For the initial field exposure studies, two sizes of stone samples were chosen: slabs measuring $2 \times 12 \times 24$ inches and briquettes measuring $2 \times 2-15 / 16$ $\mathrm{x} 3-1 / 4$ to $3-1 / 2$ inches cut from the slabs. The numbering scheme shown in figure 9 was used to identify the location and orientation of each briquette with respect to the slab from which the briquette was cut. The briquettes were sawn at NBS using water to facilitate cutting. Prior to sawing, the saws were cleaned to minimize contamination of the stone during cutting. To aid in securing the briquettes in their field exposure racks, two edges were bevelled as shown in figure 9.

Slabs not used in the initial exposure studies were placed in two 3-mil plastic bags and stored at or near room temperature at NBS. The Salem Limestone slabs ("SALS") stored at NBS in Gaithersburg, Maryland, along with the few slabs provided to the Indiana Geological Survey in Bloomington, Indiana, are considered standard research stone in this and subsequent acid rain studies.

* The 4 inch thick slabs were necessary for physical and mechanical tests requiring thicknesses in excess of 2 inches; they did not recelve a "smooth planar finish". 


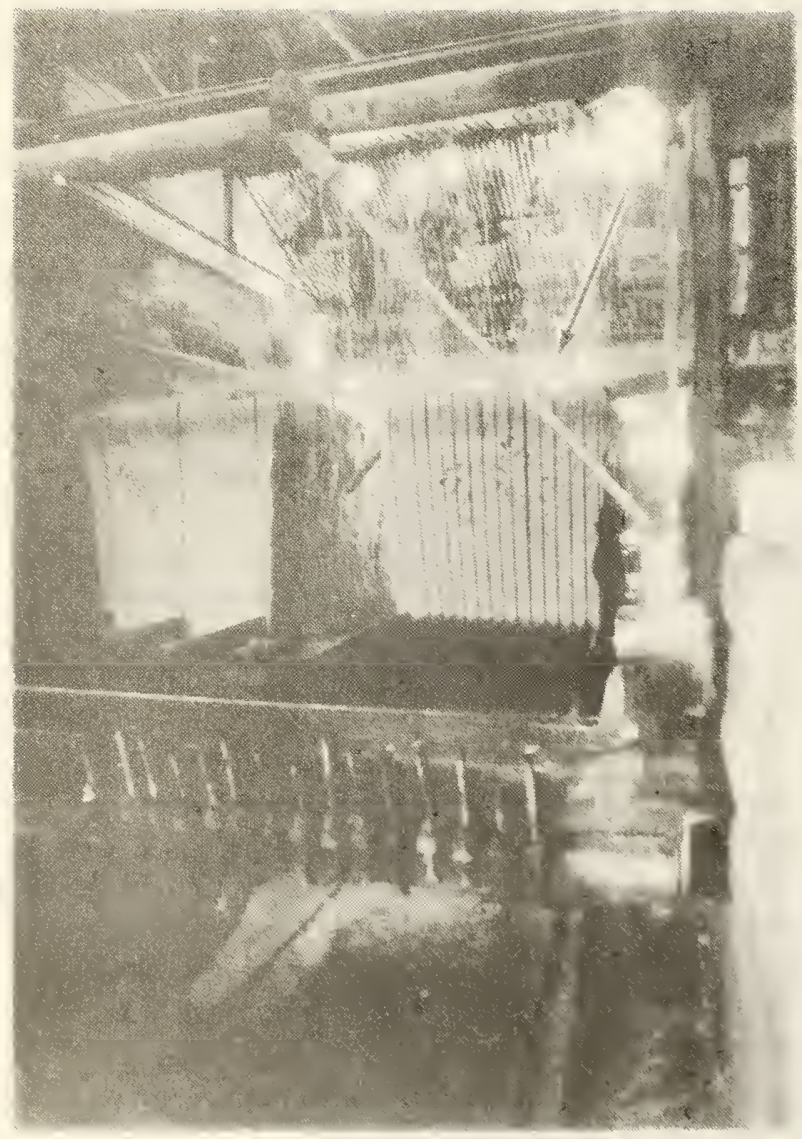

a.

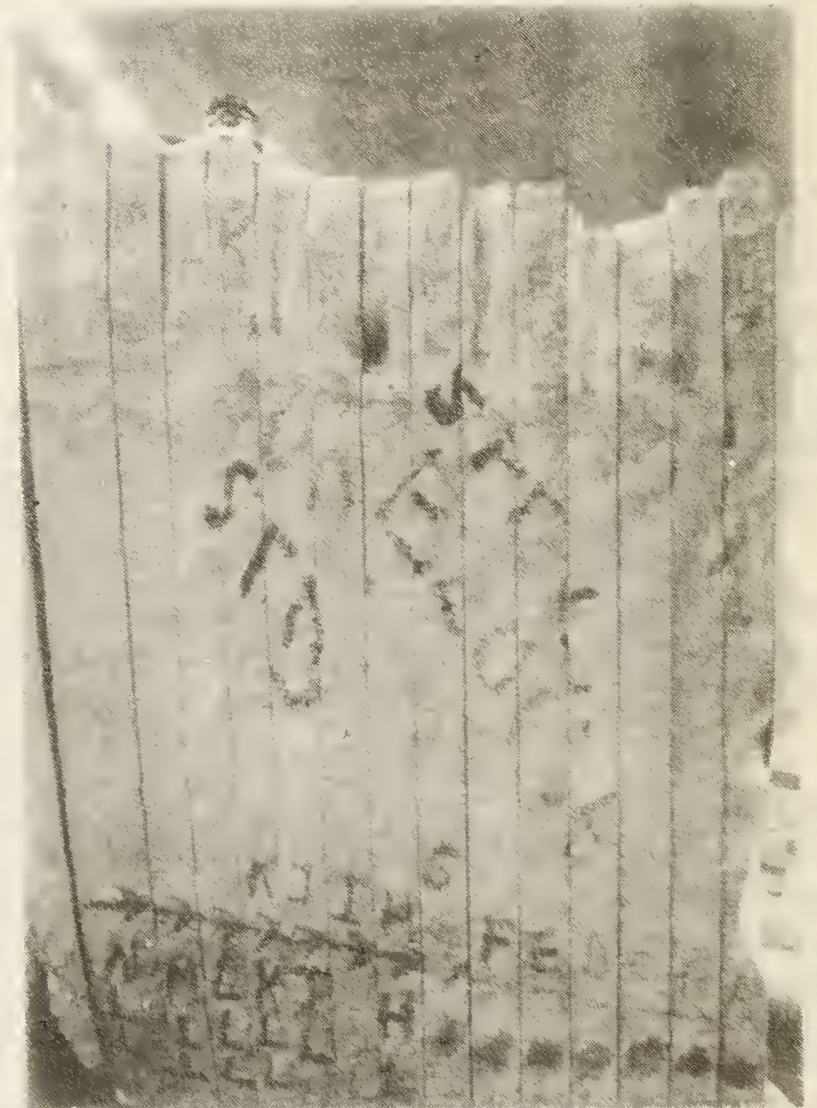

b.

Figure 4a. Study block in saw (right side, arrow) being gang sawn into thirteen 2 inch and one 4 inch thick slices.

4b. Close-up of study block after gang sawing. 


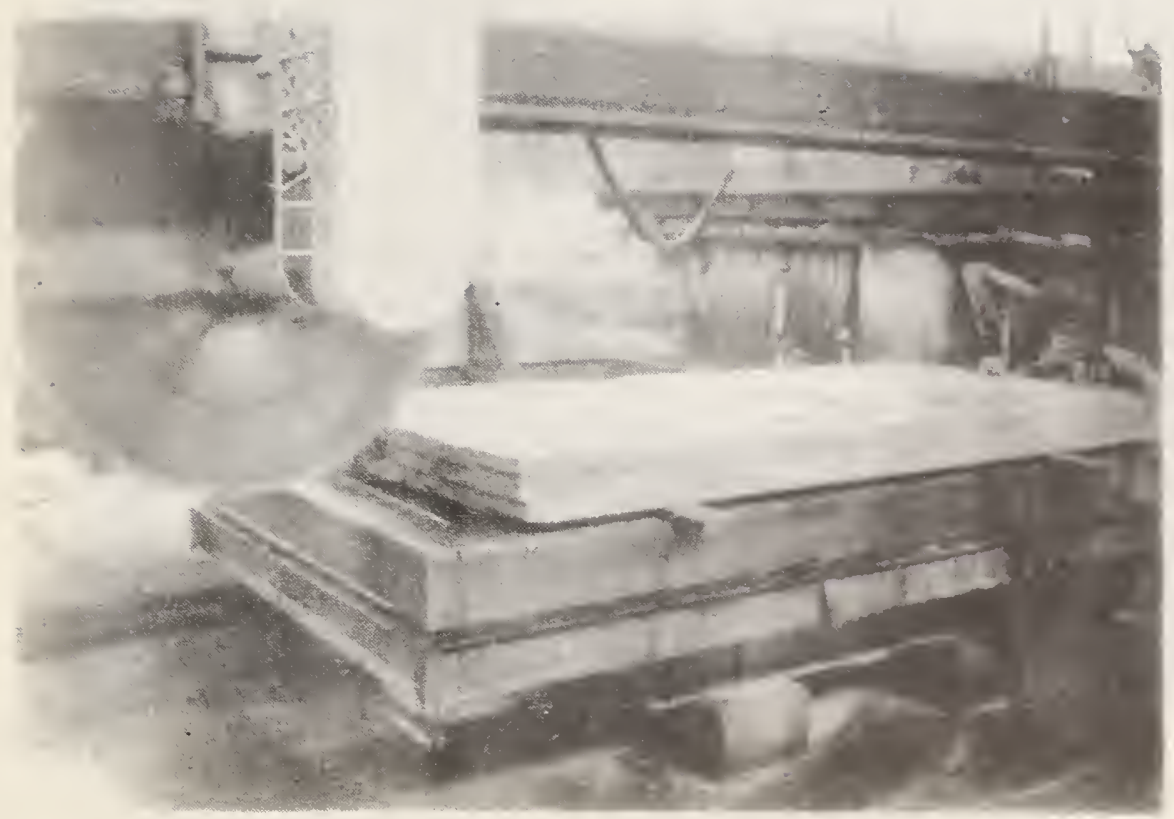

Figure 5. Three $2 \times 48 \times 108$ inch slices being sawn in half. 


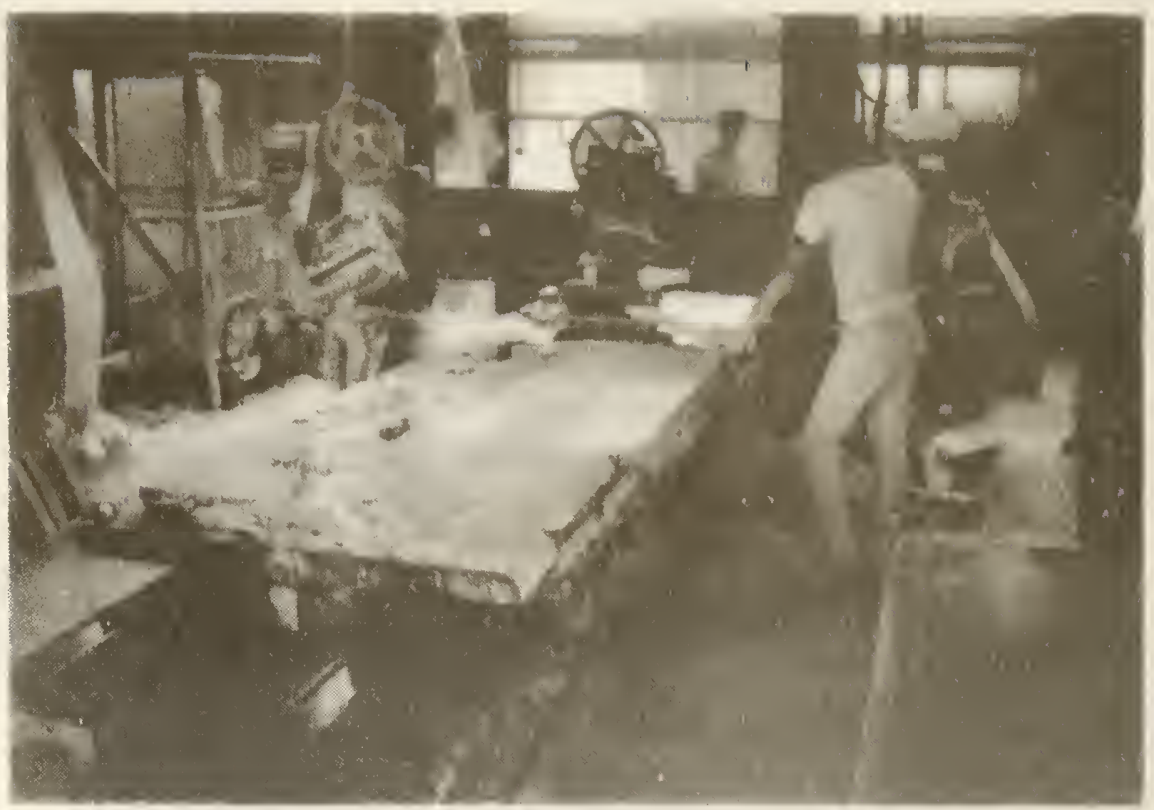

Figure 6. One $24 \times 108$ inch surface being planed to a "smooth planar finish". 


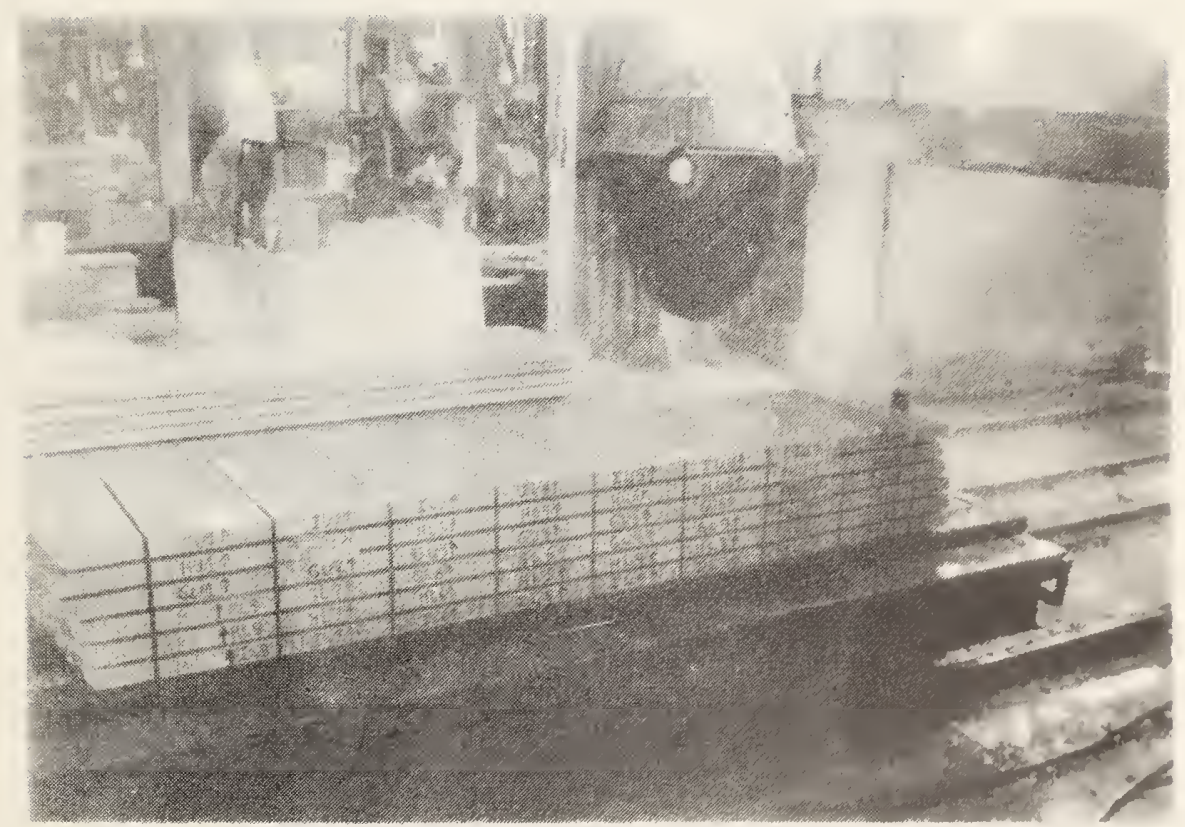

Figure 7. Six $2 \times 24 \times 108$ inch half-slices that were sawn into forty-eight $2 \times 12 \times 24$ inch slabs. 


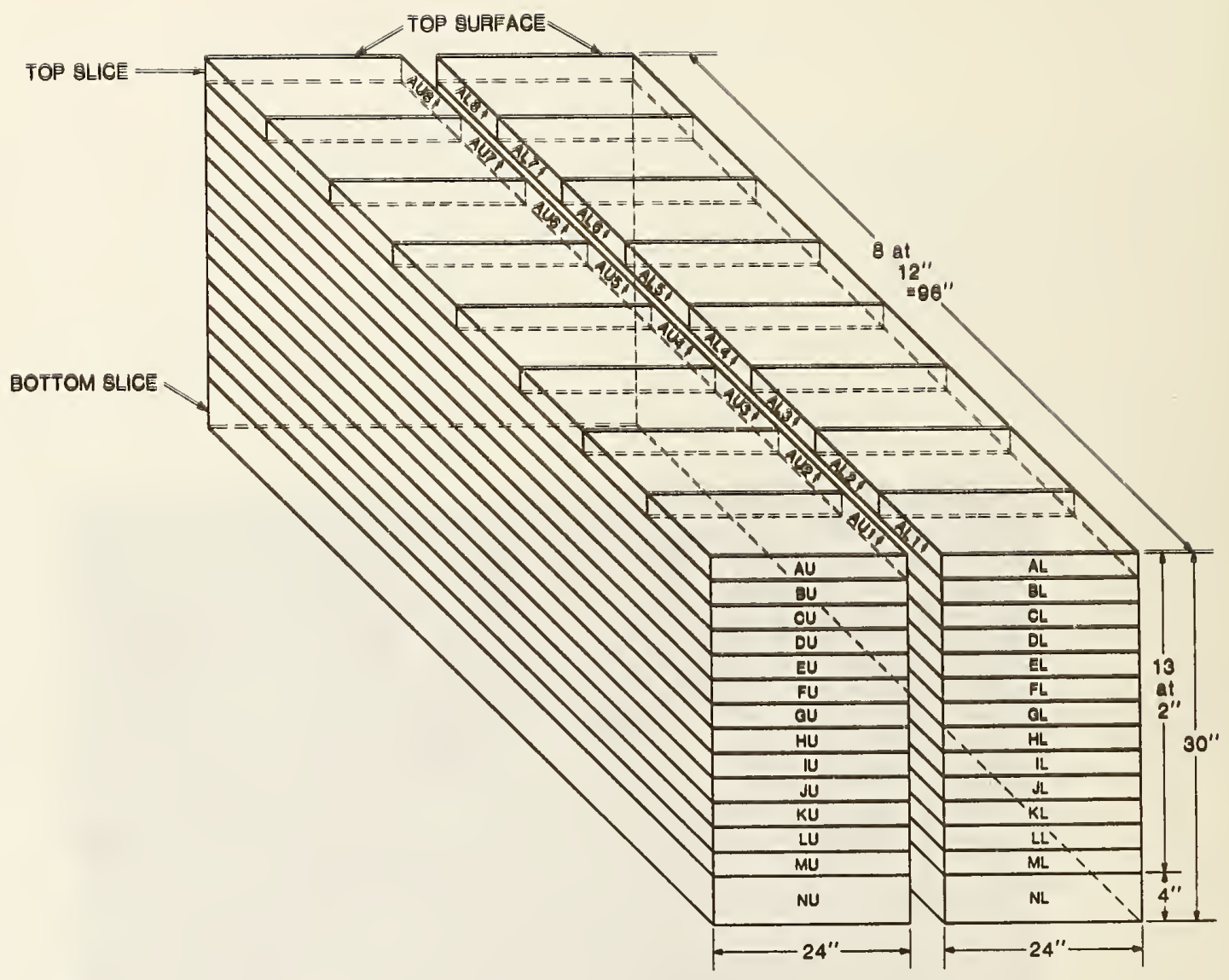

Figure 8. Labeling scheme used to indicate relative location and orientation of the two-hundred-and-twenty-four $12 \times 24$ inch slabs within the original Salem Limestone study block. The top slice of the block is on the top of the figure and includes slabs AU1 to AU8 and AL1 to AL8. The bottom slice of the block, at the bottom of the figure, includes slabs NU1 to NU8 and NL1 to NL8. Slabs A through $\mathrm{M}$ are all 2 inches thick; the $\mathrm{N}$ slabs are 4 inches thick. All slabs are: (1) labeled with a two-letter, one-number designation (e.g., AU3), and (2) marked with an arrow pointing to the upper $12 \times 24$ inch surface, the surface lying closest to the top of the original quarried block and having the "smooth planar finish". 
Table 1. Inventory of 2 (or 4) $\times 12 \times 24$ inch Slabs Provided to the USGS, Indiana Geological Survey, or Discarded Because of Defects

\begin{tabular}{|c|c|c|c|c|c|c|c|c|c|c|c|c|c|c|c|c|}
\hline \multirow[b]{3}{*}{ Slice } & \multicolumn{16}{|c|}{ Slab Designation } \\
\hline & \multicolumn{2}{|c|}{1} & \multicolumn{2}{|c|}{2} & \multicolumn{2}{|c|}{3} & \multicolumn{2}{|c|}{4} & \multicolumn{2}{|c|}{5} & \multicolumn{2}{|c|}{6} & \multicolumn{2}{|c|}{7} & \multicolumn{2}{|c|}{8} \\
\hline & $\mathrm{U}$ & L & $\mathrm{U}$ & L & $\mathrm{U}$ & L & $\mathrm{U}$ & $\mathrm{L}$ & $\mathrm{U}$ & L & $\mathrm{U}$ & L & $\mathrm{U}$ & L & $\mathrm{U}$ & $\mathrm{L}$ \\
\hline A & $c^{*}$ & b & c & & a & & & & & c & & c & b & & & \\
\hline B & & & & & a & & & & & & & & & $c$ & & \\
\hline C & & & & & a & & & & & & & & & & & \\
\hline D & & & & & a & & & & & & & b & & & & \\
\hline$E$ & & & & $c$ & a & d & & & & c & & c & & & & d \\
\hline F & & & & & a & & & & & & & & & & & \\
\hline G & & & b & & a & & & b & & & & & & & & \\
\hline $\mathrm{H}$ & & & & & a & c & & & & & & & & & & \\
\hline I & & & & $c$ & $a$ & c & & & & & & d & c & & & \\
\hline $\mathrm{J}$ & & c & & & a & & & c & c & & c & & b & & & \\
\hline $\mathrm{K}$ & & & & & a & & & & & & c & & & & & \\
\hline $\mathrm{L}$ & & & b & & a & & & & c & & $d$ & & & b & & c \\
\hline$M$ & & & b & & a & & & c & & & b & & & & & \\
\hline $\mathrm{N}$ & b & b & b & b & $a * *$ & b & b & b & b & b & b & & b & b & b & b \\
\hline
\end{tabular}

* = entry represents one 2 (or 4) x 12 × 24 inch slab-here AU1.

** = only part of NU3 provided to USGS.

$a=$ USGS performing mineralogical and chemical analyses on these slabs.

b = provided to Indiana Geological Survey for physical and mechanical tests and for future testing.

$c=$ discarded because of defects which occurred during quarrying and fabrication.

$d$ = part or entire slab provided for preliminary testing or examination as follows: EL3 to Argonne National Laboratories (ANL) and NBS, EL8 to ANL, IL6 to USGS, LU6 to USGS and the National Park Service. 


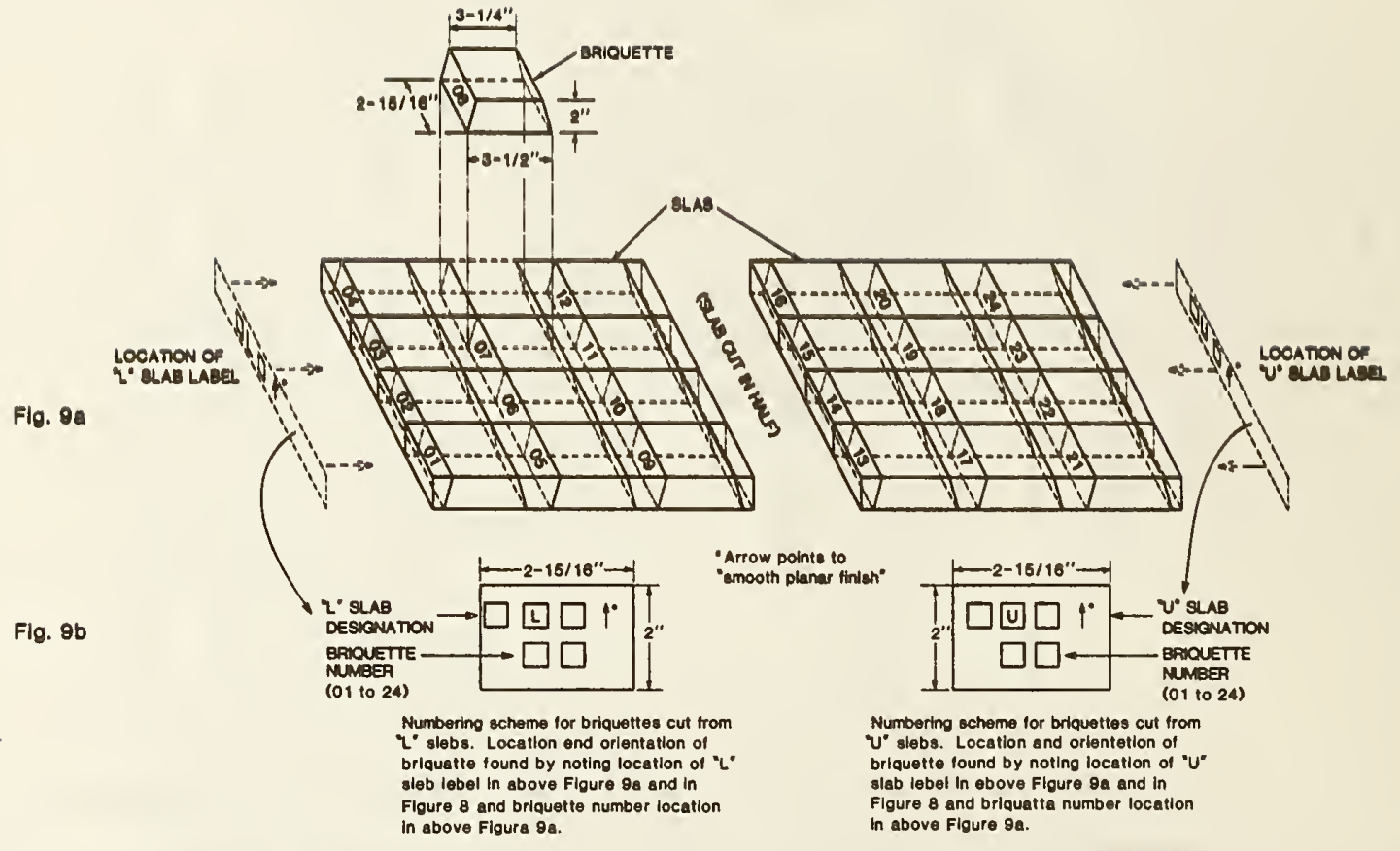

Figure 9. Numbering scheme used to determine location and orientation of twenty-four $2 \times 2-15 / 16 \times 3-1 / 4$ to $3-1 / 2$ inch briquettes cut from "L" slabs (AL1, AL2, ..., ML8) or "U" slabs (AU1, AU2, ..., MU8)see figure 8. Each briquette has the slab designation (either "L" or " $U$ ") and a briquette number (01 to 24) on 1 t. 
This stone will be made avallable to interested research scientists. For information about procuring samples contact the National Park Service (NPS), Washington, D.C.

Additional reports will be published relating to the selection, procurement, and description of other bullding stones as well as progress reports on the observed chemical, mineralogical, and physical changes of the test stones situated at the various weathering monitoring stations. 


\section{ACKNOWOWE DGMENTE}

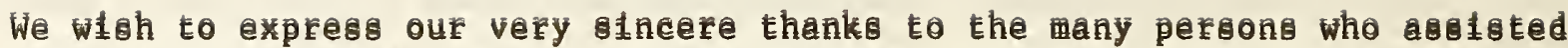
us in the procurement of the salem timestone used in this otudy! to Mo. Susan Sherwood of the National Park Service and the ramberg of the "otone group," Mater1a1s Effects Task Group (part of NAPAP) and to the many in the State of Indiana who gave so generously of thelr time; particularly Dr. John B. Patton, State Geologist and Professor Robert Blakely, both of the Indiana Geological Survey, Bloomington, Ind1ana; Mr. William H. McDonald, Executive Director, the Indiana Limestone Institute of America, Inc., Bedford, Indiana; Mr. W. Clayton Holmes, General Manager, Independent Limestone Co., Bloomington, Indiana; and Mr. Wilbur C. Bybee, President, Bybee Stone Co., Ellettsville, Indiana. 


\section{REFERENCES}

1. Indiana Limestone Institute of America, Inc., Handbook, Bedford Indiana, 1982-83.

2. McGregor, D.J. (1963), High-Calcium Limestone and Dolomite in Indiana, Ind. Department Conservation, Indiana Geological Survey Bulletin No. 27, 76 pp.

3. Patton, John B. (1953), Petrology of the Salem Limestone (Indiana Building Stone), Abs. Econ. Geol., v. 48, p. 331.

4. Patton, John B. (1974), Glossary of Building Stone and Masonry Terms, Indiana Geological Survey, Occasional Paper 6, 15 pp.

5. Patton, John B. (1982), The Salem Limestone in the Indiana Building-Stone District, Department of Natural Resources, Indiana Geological Survey, Occasional Paper $38,31 \mathrm{pp}$.

6. Rooney, L.F. (1970), Dimension Limestone Resources of Indiana, Department of Natural Resources, Indiana Geological Survey, Bulletin 42-C, 29 pp.

7. Smith, Ned M. (1966), Sedimentology of the Salem Limestone in Indiana, Ohio Journal of Sci., V. 66(2), Pp. 168-179. 
NBS-1 14A (REV. 2-80)

U.S. DEPT. OF COMM.

BIBLIOGRAPHIC DATA

SHEET (See instructions)
1. PUBLICATION OR REPORT NO.

NBSIR 84-2905
2. Performing Organ. Report No.

3. Publication Date

July 1984

4. TITLE AND SUBTITLE

Selection, Procurement, and Description of Salem Limestone Samples Used to Study the Effects of Acid Rain

\section{5. $\operatorname{AUTHOR}(S)$}

Malcolm Ross and Larry Knab

6. PERFORMING ORGANIZATION (If joint or other than NBS, see instructions)

7. Contract/Grant No.

NATIONAL BUREAU OF STANDARDS

DEPARTMENT OF COMMERCE

U.S. Geological Survey

WASHINGTON, D.C. 20234

and

Reston, Virginia 22092

8. Type of Report \& Period Covered

9. SPONSORING ORGANIZATION NAME AND COMPLETE ADDRESS (Street. City, State, ZIP)

U.S. Department of the Interior

National Park Service

Contracting Policy Branch

Washington, DC 20240

10. SUPPLEMENTARY NOTES

Document describes a computer program; SF-185, FIPS Software Summary, is attached.

11. ABSTRACT (A 200-word or less factual summary of most significant information. If document includes a significant bibliography or literature survey, mention it here)

This report describes the selection, procurement, and description of the Salem Limestone to be used in field exposure tests to assess the effects of acid rain on building stone. The rationale for choosing Salem Limestone is given and a brief geological description of the stone is provided. Preparation of the stone samples for field exposure, including cutting, surface finishing and labeling, is presented.

12. KEY WORDS (Six to twelve entries; alphabetical order; copitolize only proper names; ond seporate key words by semicolons) acid rain; building; dimension stone; exposure; geology; 1imestone; Salem Limestone; stone

13. AVAILABILITY

X] Unlimited

$\square$ For Official Distribution. Do Not Release to NTIS

[] Order From Superintendent of Documents, U.S. Government Printing Office, Washington, D.C. 20402.

[X] Order From National Technical Information Service (NTIS), Springfield, VA. 2216I
14. NO. OF

PRINTED PAGES

15. Price

$\$ 7.00$ 

